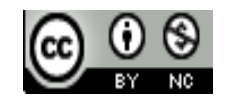

Journal of Education, Teaching and Learning is licensed under

A Creative Commons Attribution-Non Commercial 4.0 International License.

\title{
Ternate Historical Site as an Object Based Education for Sustainable Development
}

\author{
Suswandari \\ Universitas Muhammadiyah Prof. DR. HAMKA, Jakarta, Indonesia \\ E-mail: bsuswandari@yahoo.com
}

\begin{abstract}
This study aims to classify the historical sites of Ternate based on the timeliness of its existence. This study uses a critical qualitative historical approach and is conducted in several locations related to the history of Ternate. Data relating to the physical facts of Ternate history sites, then the location of research in the Ternate region of North Maluku. Data were collected from several findings and poured in filed notes. Then do the sorting and grouping to found description. Data were analyzed using critical historical analysis techniques. The Ternate history sites identified in this research consist of Ternate Museum of Ternate, Ternate Great Mosque, Kastela Fortress, Toluko Fortress, Kalamata Fortress, Oranje Bull, and Nala Fortress. Seven sites are conditions vary and still require government intervention to be used as an object of tourism which can then become an economic power for the people of Ternate. With the Education For Sustainable Development (EDS) approach, historical site development takes care of the needs and involves the community directly with full results for the benefit of the people of Ternate and the wider Indonesian community.
\end{abstract}

Keywords: Ternate; Historical Site; Education for Sustainable Development

\section{INTRODUCTION}

Ternate is one of the areas of the Maluku Islands group by the Portuguese explorer Alfonso d'albuquerque is said to be a very rich island of spices and needed European society at that time. The journey of imperialism and colonialism The Portuguese to the East was encouraged to find the spice trade center of the first hand. The fall of the Strait of Malacca in 1511, became an important sign for Western power in the region of Southeast Asia until finally, the Portuguese managed to instill its power in the territory of the Sultanate of Ternate. The Sultanate of Ternate or also known as the Kingdom of Gapi is one of the four oldest Islamic kingdoms in Indonesia. The Sultanate of Ternate was established in 1257. The fertility and natural wealth of Ternate Sultanate, especially cloves, pepper, and nutmegs became the main attraction for Western merchants. Therefore, in its historical record, the Ternate region is at least occupied by three Western nations, namely Portuguese, Spanish and Dutch. Traces of the history of these three Western colonies can still be found until now, as a historical site in the Ternate region. Historical sites are an important artifact for historical researchers as well as other citizens to be able to find out their own nation's past travels for the benefit of the future. Studying history through historical sites is an important part of the character and identity of a nation.

Education for Sustainable Development (ESD), often referred to as Education for Sustainable Development, is one approach to the awareness raising of the historical values of a nation through existing historical sites. Education to support sustainable development in relation to historical sites is an education that gives everyone the awareness and ability to contribute better to sustainable development for the present and future based on historical site findings found. In relation to this, Ternate as a rich area of pre-colonial and colonial history sites needs to be identified as an effort to preserve and preserve and preserve the historical values contained in it for the present and future generations in instilling awareness of the history of the nation. History makes a man be wise, as Sir Seelay said. The identification of historical sites can be useful in educational education, ie awareness of history. Politically can be used to instill a sense of love of the homeland, and economically can be used as a center of tourism, cultural center as part of the nation's character. In the midst of increasing awareness of Indonesian tourism supported by increasingly easy transportation facilities, the identification of historical sites in Ternate can be part of a tourist magnet visit Ternate.

Understanding of Historical Sites

History Science by S.K.Kochhar (2008) is called the mother of the social sciences because this science has been born and developed long before other social sciences develop. History examines human life that occurred in the past in the scope of time as an essential element of history. If we can find relics of an event involving humans such as 
temples, fortresses, broken pots, currencies, ruins, manuscripts, books, photographs, stamps are part of the object that historians learn (Louis Gottschalk, 1985). History is learned through various forms of relics called historical sites. The site is a plot of land containing ancient remains, its location can be on land or sea, in a cave, on a river bed, or in the mountains (Junus SA, 2014). On regular sites found objects, ruins of buildings, or ancient structures that are at least 50 years old. Ancient temples, ancient mosques, ancient tombs, or megalithic buildings are the ancient types of buildings.

In the Act No. 11 of 2010 on Cultural Heritage, the site definition is described as follows: "Cultural Heritage Sites are locations located on land and/or in water containing Cultural Heritage, Heritage Buildings, and/or Cultural Heritage Structures as results of human activities or evidence of events in the past. Various forms of relics are part of what is called the fact of history. Historical facts occupy a very important position for a historian because the fact by Patrick Gardiner (Sjamsudin, 2007) is defined as what really happened. New facts can speak after historians choose to speak (Sjamsudin, 2007).

Learning history through historical facts and historical sites has the objectives (SK Kochhar, 2008) as follows: (a) Developing an understanding of ourselves, to know who we are necessary historical perspective, (b) Providing an appropriate picture of the concept of time, space and community, relation to the present and past, between local and other far-flung territories, (c) Making society able to evaluate the values and outcomes achieved by their generation, to measure the success that has been achieved in their time, (d) ) Teaches tolerance for differences, (e) Embedding intellectual stance, awakening awareness that interaction between humans is not simple. The social process is a vast complexity, (f) Teaching moral principles, history describes good and bad deeds, as teachers in life, ( $g$ ) Embracing future orientation, encouraging citizens to have a vision of life ahead and how to achieve it, (h) Strengthen nationalism.

Ternate is an area in Eastern Indonesia that can present various facts about its extent that is declared a historical site because it is protected by law. As an area once used as a center of imperialism and colonialism in Eastern Indonesia, this region leaves behind an amazing historical track record. This historical heritage should be its own potential for the community and government of Ternate through various activities of maintenance, safeguarding, and preservation. Ternate history sites include Kedaton Sultan Ternate Museum, Sultan Ternate Mosque, various forms of Portuguese colonial and Spanyo and Dutch colonial heritage such as Portuguese fortress, Santa Lucia fort, Santo Paolo fort, Santo Pedro fort, Fortress Ford Oranje. These heritages are part of the Ternate cultural heritage, which can be a source of value to learn from the younger generation and utilized for its potential for present and future life.

Education For Sustainable Development (ESD)

Education for Sustainable Development (ESD) or education for sustainable development has actually emerged since 1997 along with the Greek Declaration of Thessaloniki. Education for Sustainable Development itself is actually an evolutionary form of Environmental Education (PL) which began in 1972. The fundamental change of ESD and the OT is to the issues discussed and the learning process approach. In the PL issues discussed only focused on environmental issues and approaches to learning process is still top down (from above), so it can be said is the process of knowledge transfer. While in the ESD issue is discussed more broadly, which concerns the environment, social, economic, and environmental impacts. Education-based sustainable development is education that inserts insights and concepts widely, deeply and futuristic about global developments, cause and effect relationships, and how to limit it. In addition, ESD-based education is an education that awareness and capability for all (mainly future generations) to contribute to a better future for sustainable development in the present and future.

Education for Sustainable Development (ESD) is a dynamic concept as well as a new vision in education that focuses on empowerment efforts to be responsible for creating a sustainable future (Philip Suprastowo, et al, 2010). ESD is an attempt to change attitudes and lifestyles for positive transformation of positive values in society such as (a) respecting human values and human rights, (b) appreciating future generations and commitment to intergenerational responsibility. (c) Respect and care for community life that includes the protection and improvement of ecosystems. (d) appreciate cultural diversity and build tolerance of local and global cultures. Sustainable development can be achieved through education because education is a means to change perceptions, attitudes and human behavior (in Yulipriatno, et al, 2013). The Johannesburg Summit in 2002, expanding the vision of sustainable development and reaffirming educational goals in the millennium development goals and education for all education for all set forth in the Dakar framework for action, and proposing the Decade of Education for Sustainable Development / DESD). The United Nations, in its general session at the 57th session of 2002 declared the period 2005 2014 as DESD. UNESCO was appointed to guide the decade in order to play its key role in developing quality standards in education for sustainable development (Kemdiknas, 2010a in Yulipriatno, et al, 2013).

Indonesia responded positively to the Decade of Education for Sustainable Development (DESD) discourse. The Ministry of National Education (in Yulipriatno et al, 2013) places education for Sustainable Development as one of the educational paradigms in Indonesia, namely: education produces human noble beings that are a blessing to all the worlds. Such a man meets his needs by taking into account the needs of present and future generations (intergenerational sustainability).

In the context of development and empowerment of the ESD community in the view of Oteng Haridjaja (2014) has the following functions: (a). Through ESD, capacity building of communities or nations capable of developing, developing and implementing an activity plan that leads to 
sustainable development is an activity that supports sustainable economic growth by considering several ecosystems, such as: Development of human resource and technology quality, and diversity, social justice, harmony and cultural sustainability, balance of production and consumption, etc. (b). Through ESD educates people aware of the individual responsibilities to be contributed, who respect the rights of others, nature, and diversity, can make responsible choices/decisions, and be able to articulate them in action. (c) Through ESD, we are together committed to contributing to a better life, a safer world for all of us, both present and future for our children and grandchildren. This is a comprehensive understanding of complexity and diversity and how to change all development/development towards sustainability, and implemented through prudent planning and implementation, and disseminated effectively and widely.

Furthermore, as a concept of development ESD has several purposes as follows: (a) Development that can meet the needs of the present generation without compromising the ability of future generations to meet their living needs, (b) Improving the quality of human life while remaining alive in the ecosystems carrying capacity, c) Beneficial to all beings on this earth for the present and the future.

There are three perspectives in ESD: (1).Sociocultural perspective: examines social institutions and human roles in change and development. Develop agreements and be aware of differences, including harmony, harmony and empathy, democracy, participation, social justice: race, gender, certain, cultural and cultural diversity, Development of environmentally friendly Sain-Tek, (2).Environment perspective is an awareness of natural resources, sensitive environment. (3).Economic perspective, a sensitivity to the limitations and potential of economic growth and its impact on society and the environment, includes sustainable growth, equality of rights and opportunities, production and consumption balance. These are the pillars in ESD that complement each other.

Maintenance, maintenance, and handling of historical sites in the context of identification require education in a broader and ESD-based context, ie conservation and adjustment without leaving previous values for future generations with more dynamic potential to suit the needs of the community. Identification of Ternate historical sites with ESD base is expected to maintain the preservation and balance of the environment while still paying attention to people's living needs.

\section{RESEARCH METHOD}

This study uses a critical qualitative historical approach as developed by Louis Gottschalk (1983). With the historical method of critical problems existing in this research is solved from the perspective of history. Given the complexity of the problems studied in the science of history, the most important are to deal with the historical evidence found and relate it to aspects of human life in general. In this regard, the first step in this research is to collect the historical data of Ternate from various sources in various historical sites in Ternate, libraries, web, newspapers and other social media. The second step, done the selection to find data that is authentic, accurate and relevant. The third step is to process and analyze the data that has been selected by making an interpretation after through internal and external criticism.

The scope of the critical historical approach in this study includes the selection of research subjects, data collection, selection and analysis of data and the preparation of historical descriptions of the facts found. Historians will always remember that historical events are einmalig, only once happened, therefore thoroughness, patience, and foresight become the main capital in this study. This research was conducted in several locations, related to the history of Ternate. For data relating to the physical facts of the Ternate history site, the research location in Ternate region of North Maluku. In addition, the supporting data is done in various libraries and other social media that are tested. This research is focused on the existence of historical sites in Ternate with all forms of description from supporting literature. The presence of informants is also needed to gain their perception of the historical sites in Ternate and efforts to analyze them. Data were collected from several findings and poured in field notes. From this field, the note is then sorting and grouping to find the description. Data were analyzed using critical historical analysis techniques.

\section{RESULT AND DISCUSSION}

\section{A. Ternate City Government Policy on Historical Site as a Cultural Heritage}

Ternate City is a regency/municipality in Indonesia that has been over 763 years since the region has been in the form of a sultanate with all its dynamics in the colonial era, the Old Order and the New Order. In colonial times Ternate became the target of invaders because of its spices. In the Ternate region was visited by Portuguese, Spanish and Dutch colonists. Each of the colonial government has its own footprint and the trail becomes a marker/site of Ternate's past. In the time of the Sultanate of Ternate once led by a sultan who is very tolerant of diversity. In view of Darmawijaya (2014) Ternate is referred to as a heritage city because Ternate keeps a variety of tangible heritage (tangible heritage), non-material heritage (intangible heritage) which in history called history site.

Ternate's historical sites are sturdy old buildings such as the fortress, the mosque and the imperial palace itself. For the sake of securing the spice trade, Portuguese, Spanish, and Dutch built fortresses in North Maluku. In Ternate, Tidore, and part of the Banda Islands stood the remains of a fortress that once witnessed the glory of the Indonesian herbs. In Ternate itself, there are eight surviving fortresses, namely Tolukko, Kalamata, Kastela, Oranje, City of Promise, Bebe, Naka City, and Takome. From the Dutch record, there are at least 12 fortresses in Ternate, including a wooden fortress, Kalafusa Fortress, but the rest is not found traces.

The involvement of the Ternate Municipal government in handling various historical sites is included in 
the concept of preserved cultural heritage objects. Some Ternate government policies, against cultural heritage objects in the Darmawijaya record (2014) as follows: (1). Unify the various urban development with the effort to preserve the city's heritage, either in the form of the value of ancestral or other values through local regulations. (2). Establishment and management of cultural heritage in accordance with Law No. 11 of 2010 on cultural preservation, (3). Preservation of old buildings for the common good. The effort to preserve historical sites as a cultural heritage of Ternate is done as an effort to strengthen the identity of Ternate City itself is multicultural, based on religious teachings, and its people live in harmony. Thus, what is done by the Ternate Municipal government related to the preservation of historical sites, the cultural heritage of the city of Ternate is not intended to restore the glory of Ternate itself.

\section{B. Heritage Site of Ternate City Heritage.}

Ternate is a symbol of the glorious past of the Indonesian nation. This is where the largest spice-producing center in the world was born. Lots of heartbreaking stories struggles and battles to defend the city. The city's historic forts and buildings are silent witnesses that still keep the stories (communityhistoria.com in Shandy Marcelino Alfons, without years). As a city of more than 763 years with the dynamics of the political, social, and economic system, Ternate has many historical sites that currently serve as cultural heritage or in regional regulations called Heritage Objects (BCB). Cultural Heritage objects are the remains of the past as a trace of events that have occurred. Historical relics History is one of the potential sources in the introduction of culture, especially the culture of a particular region. In addition, BCB are also a cultural heritage that has a special attraction for the community at large about their old age (http://bentengmalut.blogspot.com/diunduh 30 June 2015).

It must be acknowledged that the awareness of the historical importance in Indonesian society has only grown in the last few decades. Historical knowledge is instrumental in the development of the nation's personality. However, that does not mean by knowing the values then we must restore the past way of life into the present. The facts of the past that we can still see and enjoy in the city of Ternate, among others, in the form of bastions of European remains, as evidence of how the wealth of Ternate with cloves tease the Europeans to come looking for "valuables" Ternate this.

So many historical sites exist in Ternate, this study will only show four historical sites as a cultural heritage with the following considerations: 1). Observe the physical condition of the building, because there are buildings that live only because the land was built with wood and burned. 2). Judging from its meaning in the history of Indonesia and Ternate, 3). Limitations of time and energy of researchers and lack of written sources about various historical sites that exist. The historical sites as a cultural heritage are referred to below.

Kastela Fort
Fig. 1

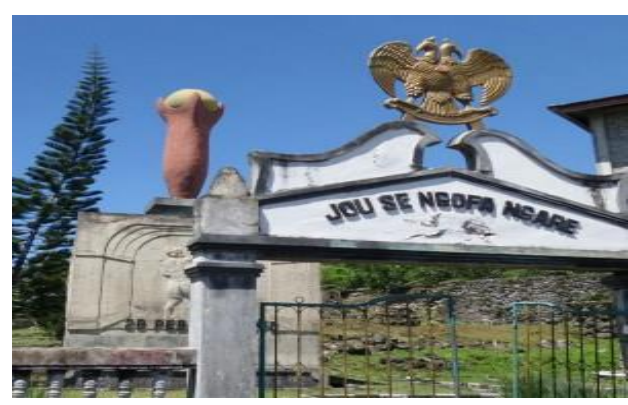

Kastela Fort

Kastela Fort is located in Kastela Village. Kastela Fort also often called the Gam Lamo Fort (origin of the name of Mount Gamalama), Nostra Senora del Rosario. Gam Lamo itself means "great village" because here it used to be a large village containing Portuguese people. The name Kastela, allegedly derived from the word fort which means the palace, because it was here once was the central palace of Portuguese government and trade. The first time this fort was built by Antonio de Brito in 1522, then followed by Garcia Henriquez in 1525. In 1530, the construction was continued by Goncalo Pereira, and in 1540 the fort was completed by Jorge de Castro. On the gate bearing the words "Jou Se Ngofa Ngare" with the symbol of two-headed garuda (Goheba Madopolo Romdidi) symbol of the Kingdom of Ternate. Jou Se Ngofa Ngare means "me and you" which is the slogan of Ternate Sultanate. This word can be interpreted as upholding togetherness.

In this Kastela fort murder of Sultan Khairun by Antonio Pimental on the orders of the Portuguese Governor Lopez de Mosquita on 27 February 1570. On the occasion, the son of Sultan Khairun, Baabullah (1570-1583) rose against the Portuguese and finally the Portuguese expelled from the fort Kastela and Ternate in 1575. After the Portuguese were removed from Ternate, Spain entered and the fort was occupied by Spain. During the siege and assault of this fortress by Spain in 1606, and Spain quickly took over and took fifty-three large copper cannons inside the fort. In the raid in the city of Ternate, they found other valuable spoils. Since then Ternate is controlled by the Spanish (http: //bentengmalut.blogspot.com.unduh 30 June 2015). Kastela Fort is one of the objects of cultural heritage, it's just around the fort there are new buildings that disturb the beauty and historical value of the fort Kastela itself. This is reinforced by Law no. 11 Year 2010 About Cultural Heritage, there is a prohibition to change or add buildings that do not support the function of the cultural heritage.

Toluko Fort 


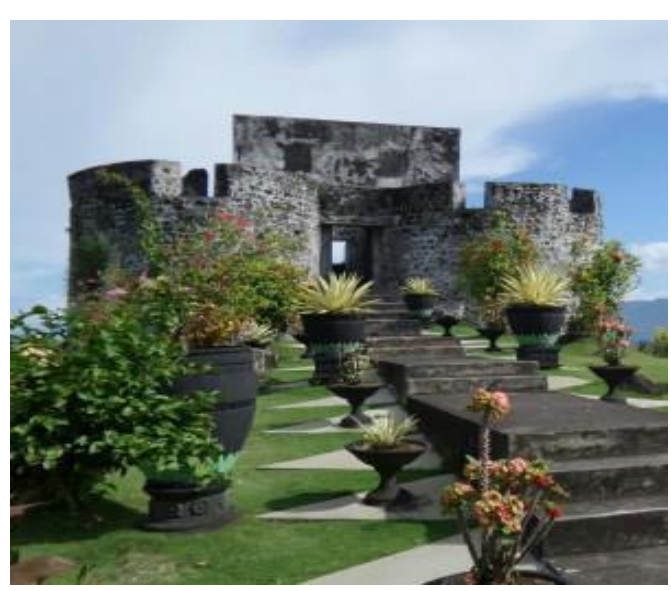

Fig. 2 Toluko Fort

Toluko Fort is one of the historical sites of Ternate and is part of a protected cultural heritage object. The fort was originally built by Francisco Serao (Portuguese) in 1540, later renovated by Pieter Both (Dutch) in 1610. The fort is often called the Holandia fortress or Saint Lucas, located in the northern part of downtown Ternate, with the direction of 800 LU. The Dutch East Indies government in 1661 allowed the Sultan of Madarsyah to occupy this fortress with a force of 160 men. Location Tolucco fort in the village Dufa-dufa which is $2 \mathrm{~km}$. The fort is located on a hill, so it is very strategic to oversee the trade traffic passage in the strait between Ternate, Halmahera, and Tidore. In addition, the Sultanate of Ternate can also be easily supervised from this fortress. The shape of this fort is unique, not symmetrical because it follows the contours of the existing hill. The shape tends to be rounded with two bastions in front and an aisle about 20 meters back between the two bastions. When viewed from above, the shape of this fort is similar to the male genitals. On the left wall after the entrance, there is a chisel of symbols that until now has not known the meaning of the chisel. If you look at the condition of the current fort, at first glance it looks good is because the fort was ever restored in 1996. Restoration done in some parts has removed the authenticity of the building. This is exemplified by the loss of evidence of underground tunnels connected directly to the sea, which according to the surrounding community stems from the lower chamber within the fort. Likewise with some patching of parts that are detached from the building, which uses modern materials prominently. The reduced authenticity of the fort due to the restoration that has been done clearly will reduce the aspect of information that can be shown by the data artifacts contextually.

\section{Kalamata Fort}

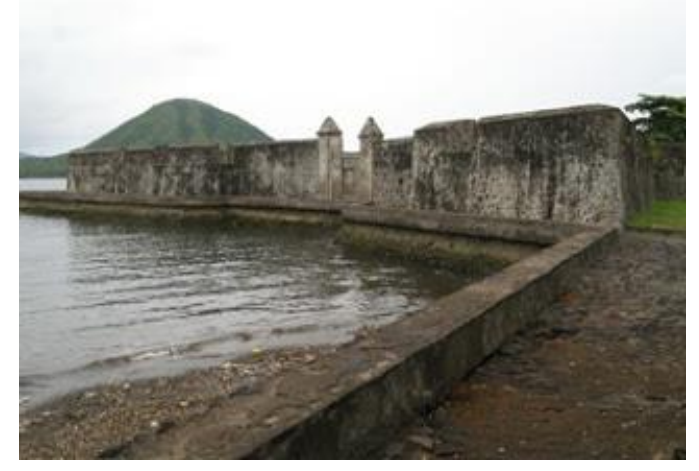

Fig. 3 Kalamata Fort

Kalamata Fort is often also called the fort of Santa Lucia or also the Red Woods. The fort was originally built by Pigafetta (Portuguese) in 1540, then restored by Pieter Both (Dutch) in 1609. In 1625 the fort was once emptied by Geen Huigen Schapenham, then in 1672 by Gils van Zeist. This emptied fort was later occupied by the Spanish until 1663. After occupation by the Dutch, the fort was repaired by Major von Lutnow in 1799. The name of Kalamata fort was taken from the name of a Prince of Ternate who died in Makassar in March 1676. Kalamata Fort the locals called the Fort of Promise City was built by the Portuguese ruler at a location at an altitude of 50 meters from sea level in the north of Ngade Village. In this fort once met two groups of troops divided by Don Pedro de Acuna, the Spanish Governor General of the Philippines who on January 15, 1606, began sailing to Maluku and on March 26 arrived at Talangame Bay. The meeting of these two well-coordinated groups of troops was in the framework of a joint attack between the Spaniards and the Tidorees of Ternate which began at dawn on 1 April 1606. At the time of the attack, the fortress had just been built. In the attack, Don Pedro mobilized his field warrior in a position to hold a shooting fence and at the same time learned that the Ternate people had a large cannon to return their fire. The Spanish movement was a threat to the fort, making the defenders of the fort speculating out of the wall to fight one on one. In the afternoon the defensive soldiers became tired and many gave up, so the Spaniards won. From this fort, Don Pedro diverted his soldiers to besiege the Fort and the town of Gammalamma, the headquarters and residence of the Sultan of Ternate at that time. But before the Spaniards reached their place (Fort), Sultan Said (grandson of Sultan Khairun) had gone (Anonymous, 1992: 84). In 1610 the fort was by the Spanish ruler equipped with six cannons and inhabited by 27 Spaniards, 20 Portuguese and some Filipinos.

The condition of the fort now physically the structure of the rock is still in good condition, despite the wall has ever occurred. It is possible there has been the renovation of the San Pedro San Pablo fort. If there has been a renovation, which is not known exactly when then the effort has eliminated the authenticity of supporting materials. This is because the present form is still very rough, so it does not reflect the historical building of the fort. Only the structure of the pond in front of the fort is still visible authenticity. Includes a wellbore near the southwest wall of this fort.

Oranje Fort 


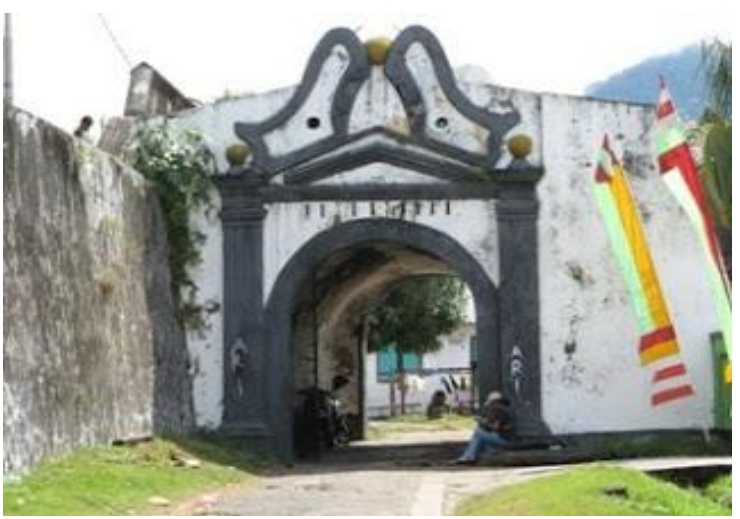

Fig. 4 Oranje Fort

The fort was built in 1607 by Cornelis Matelief de Jonge (The Netherlands) and was named by Francois Wittert in 1609. The fort of Oranje originally came from a former old fort founded by a Malay and was given the name of Benteng Malayo. Inside the fort was once the center of the highest government of the Dutch East Indies (Governor General), namely Pieter Both, Herald Reynst, Laurenz Reaal, and Jan P. Coen. In this fort was once served as the headquarters of the VOC in the Dutch East Indies until Governor-General Jan Pieterszoon Coen moved his headquarters to Batavia in 1619. The fort was able to demonstrate the ability of its defense power against the Spanish attack when the Spanish crossed quietly at night from the fort of Gammalamma (Kastela) through a difficult passage with 250 men arriving in the citadel of Oranje at dawn, can be repulsed by the Dutch in a one-on-one battle. The Netherlands with forty soldiers assisted by about a hundred people of Ternate able to defend the fort. The war in the citadel of Oranje in 1606 turned out to be a serious battle between the Netherlands and Spain in the area.

The fort walls made of brick, stone, stone and broken glass, this leaves 13 pieces of inset still inside the fort because there is no new placement activity. Although suspected, some of them have disappeared from their place of origin, this is because at the northwest corner there is absolutely no cannon. Viewed from the shape of the building at the angle is similar to the other corners as checkpoint and reconnaissance. The loss of the cannon is also known from the former foundation of the cannon on the second floor just above the gate.

The rooms on the first floor along the walls are in a state of concern. At the northwest corner, it has even buried the ground around, making it difficult to identify. In the space of $15.80 \mathrm{~m}$ at the gate and on the outer wall there is a pile of brick, which has no context with the fort. Similarly, the condition of the guard building behind the gate, all that remains is debris. Here are some pictures from the site of Oranje Fort that exist at the present moment. Here are some strong images of the fort of oranje built during the Dutch occupation.

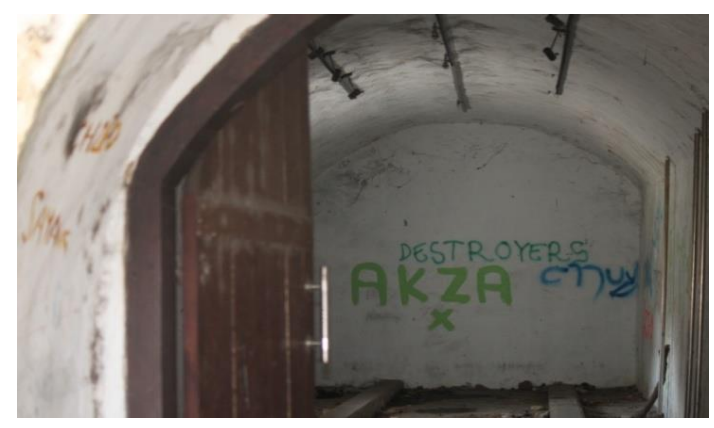

Fig. 5 Rooms in The First Floor of Oranje Fort

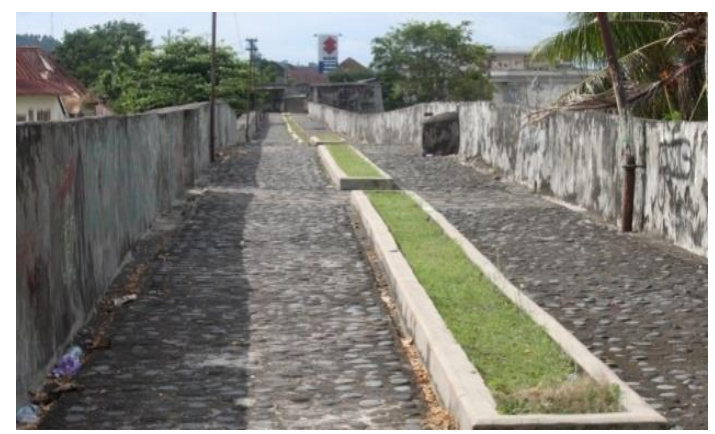

Fig. 6 Condition in Oranje Fort in 2014 (1)

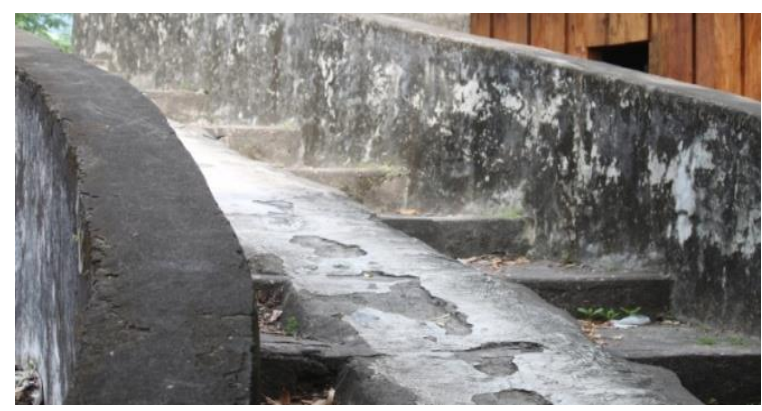

Fig. 7 Condition in Oranje Fort in 2014 (2)

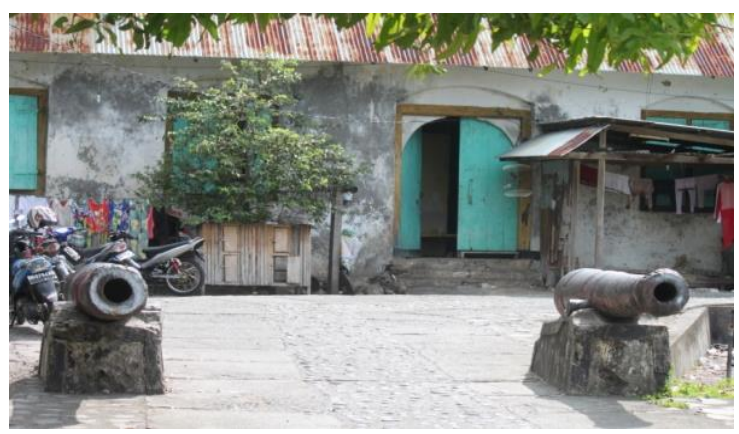

Fig. 8 Condition in Oranje Fort in 2014 (3) 


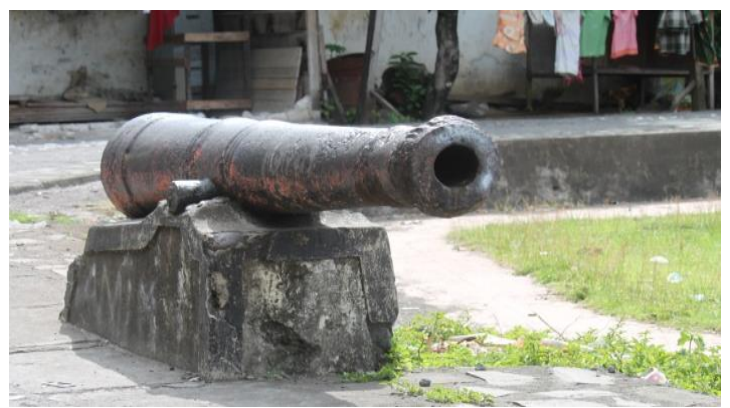

Fig. 9 Condition in Oranje Fort in 2014 (4)

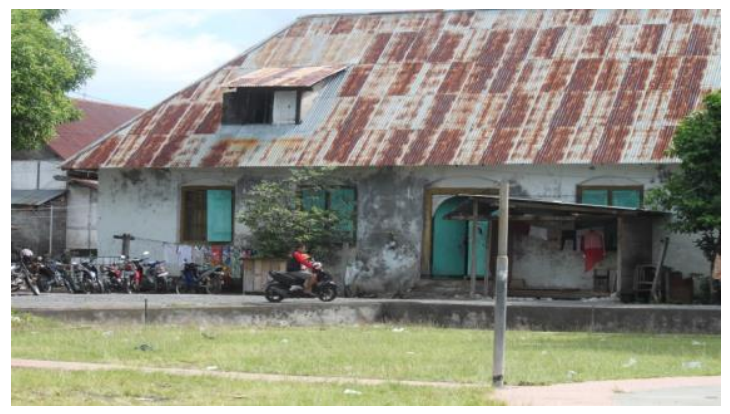

Fig. 10 Condition in Oranje Fort in 2014 (5)

The above five pictures are taken in 2014, showing the current conditions of the Oranje Fort. In terms of building, the material building is made of good quality material even very good because the wall that can be seen at the moment is still the original building. It's just that the fort's surroundings are filled with people's homes and are now in the process of revitalization.

Kota Naka Fort

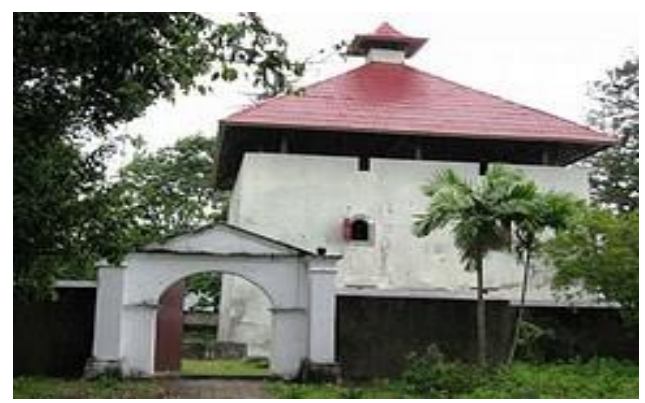

Fig. 11 Kota Naka Fort

The fort was built by the Dutch East Indies government in the 18th century. Located just a few meters to the left of Kedaton (Sultan) Sultan Ternate on a hill. The fort is named after the mention of "Naka" (jackfruit), which according to the community around it is related to the smell of jackfruit that can be smelled from a distance. Have there ever been a jackfruit tree, so far not known with certainty? This is equivalent to the function of this fort, which is to oversee the movements of the sultan in the administration of government in addition to Dutch for. This means that the news of this fort spread more quickly in the community about the condition of the kingdom(https: //
recognizeTernate .files.wordpress.com / 2014/08 / kotanaka3.jpg). Currently, the fort of Naka City has increased the structure of the wall, rising 2 (two) meters from the upper limit of the original wall. So even with the building inside, now is a small house in the form of most. On the wall of the front wall, has turned into a wall decoration wall-like garden wall.

Kedaton Ternate Museum

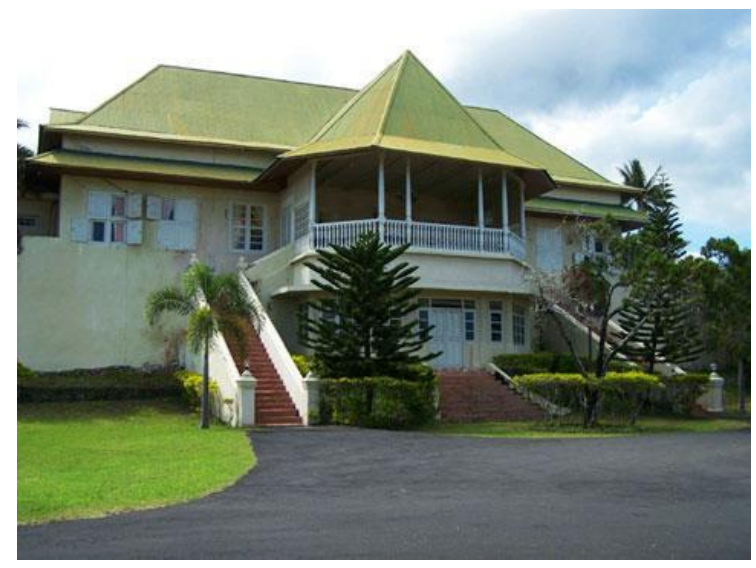

Fig. 12 Kedaton Ternate Museum

Kedaton Kasultanan Ternate Museum is proof of political, social and economic history and culture for the people. Kedaton is still awake and maintained and at certain times used to welcome guests or other customary activities. Kedaton Museum is also one of the tourist destinations for people visiting Ternate (http://www.suararadio.com/wpcontent/uploads/2012/03/ista na-kesult-Ternate 1.jpg).

\section{Kedaton Ternate Mosque}

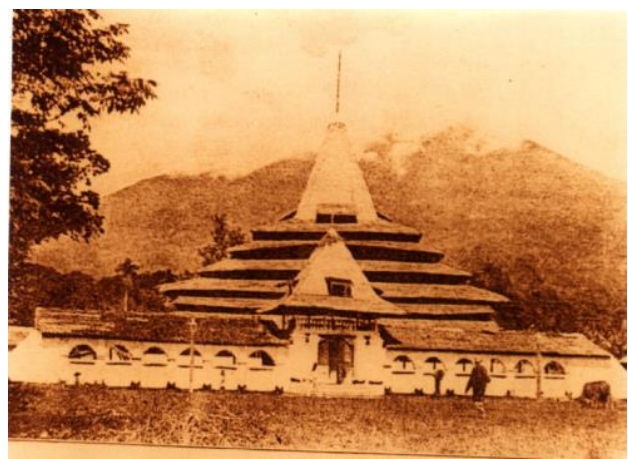

Fig. 13 Kedaton Ternate Mosque

Islam entered Maluku or Ternate, according to Western writers, in about 1460 . Antonio Galvao noted that Islam had entered Ternate North Maluku 800 years ago. Antonio Pigafetta, who arrived in Tidore in 1521, said that the Muslims were already in North Maluku (Masinambow, 1987: 327http: //aresearch.upi.edu. Ips 0603167). The first king to convert to Islam was the king of Ternate in about 1460 was Gapi Baguna or Kaicil Si a (1432-1465). From that opinion, indicates that Islam entered in Ternate begins 
with its king embraced Islam. This is in line with the opinion of the informants interviewed confirming that there are a number of Ternate philosophies which indicate the inherent "Islamic fire" in the local tradition of Ternate society. One of the assumptions that still survive is the statement of Mudafar Shah (Sultan of Ternate, who just passed away), that Islam in Ternate is even earlier than Islam in Serambi Mecca of Aceh. It is as something to imply a strong perspective of "Ultimate Islam" in the ordinary life of the people of Ternate, or at least the palace elite circle, in view of Islam. According to Antonio Galvao, in every kingdom, there is a General Casis (Kadhi), a kind of pope or priest in the Christian religion (Jacobs 1971: 87). Kadhi heads the mosque's upper mosque of the Sultanate, consisting of four imams, four modim (muadzin). He heads the officers of the other mosques in Ternate, in the same order as the imperial mosque. Kadhi, the priests, and preachers are included in what is called the bobato hereafter, while Jogugu, the sea captain, the law and the secretary are called the bobato of the world (http://aresearch.upi.edu/operator/upload/d_ips_0603167_chapter4f).

In the nineteenth century, most of the population of the territory of the sultanate of Ternate had embraced Islam and some were Christian and the primitive belief among the Alifuru people. After the king embraced Islam and accepted it in the government structure, this meant that Islam became a royal religion. Therefore the local authorities must accept the religion of Islam. There was a massive conversion of the religion of ignorance (primitive) into the religion of Islam, especially among the rulers and their families. The ruling treatment of a Muslim population as a first-class citizen and other residents as second-class citizens is a favorable condition for the transition of religion. This is especially true for the inhabitants who inhabit the coastal area and close to the ruling center in the area or the social group of the rulers of the time. Kedaton Mosque Ternate as in the picture below (http: //www.indonesiaheritagenet).

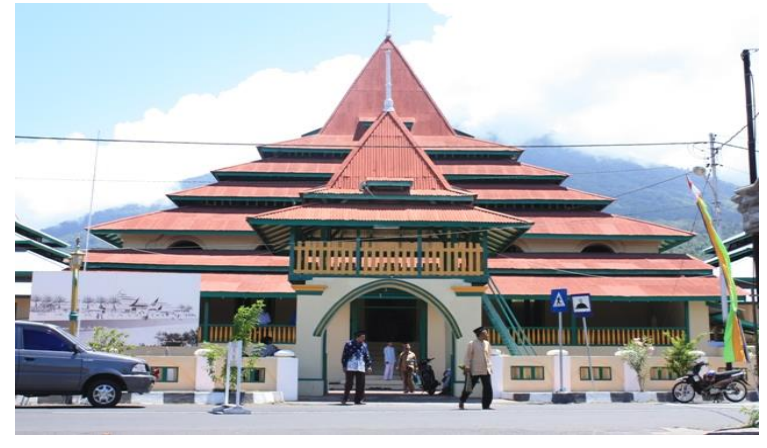

Fig. 14 Kedaton Ternate Mosque in 2014

\section{Development of Education-Based Tourism For Sustainable Development in Ternate City}

\section{Ternate as a Tourist Destination}

In the current global era, one of the efforts to improve the welfare of the community is supported by the development of tourist centers. This condition is reinforced by the increasingly easy and cheap transportation facilities, lodging facilities are more affordable and the increase of public awareness to conduct tourist visits from one area to another or abroad. This situation became one of the indicators of improving the welfare of people in a region, including Indonesia. The unique geography of Indonesia and supported by various ethnic and cultural potentials are the main attraction for Indonesian people to know other areas. Similarly for overseas visitors. During this time the island of Bali as if by only the only tourist destination in Indonesia. As a labor-intensive industry, with a large and growing domestic market, tourism is expected to contribute significantly to the program of unemployment in Indonesia (ILO, 2012).

In accordance with Law No. 10 on tourism, Chapter 1, article 1 , there are several terms pertaining to tourism itself as follows. (1) A tour is a travel activity undertaken by a person or group of persons by visiting a certain place for recreational purposes, personal development, or studying the unique attractions of the visited tourist in the interim period. (2) Tourism is a wide range of tourism activities and supported by various facilities and services provided by the community, entrepreneurs, government, and local government. (3) Tourism is a multi-dimensional and multidisciplinary tourism-related activity that emerges as a manifestation of the needs of every person and country as well as the interaction between tourists and the local community, fellow travelers, the Government, local government, and employers. (4). Attraction Attractions are anything that has uniqueness, beauty, and value in the form of diversity of natural wealth, culture, and man-made products that are the target or purpose of a tourist visit. (5). Tourism destination area hereinafter referred to Tourism Destination is geographical area which is in one or more administrative area in which there are tourist attraction, public facilities, tourism facilities, accessibility, as well as interrelated community and completes the realization of tourism. (6). Tourism business is one that provides goods and/or services for meeting the needs of tourists and the implementation of tourism.

Observing the contents of the law, the City of Ternate has all aspects of understanding in question. Judging from the amount of flight activity that exists, Ternate City became one of the tourist destinations both domestic and foreign. This is supported by the pictures of nature, natural wealth, beaches, mountains, sea, fish, lamps and special culture are very interesting. Ternate City is a unique city that is the main attraction. Moreover, the word Ternate is always associated with Tidore has been introduced to the Indonesian community through history lessons since the level of primary education, compared with the name of other regions in the region. The problem faced is the readiness of Ternate City to prepare various facilities for the tourists who come. This condition is continuously improved by conducting various development plans that also focus on the tourism development sector.

Ternate as a city of Pusaka asana has been disclosed by Darmawijaya, et al. (2014) owns many sites which are then strengthened with protected heritage area, guarded its existence and serve as national asset, regional 
asset that has important benefits for the development of regional potential including the development of character love identity local for the local community, including the residents of Ternate itself. In connection with the gal, the government of Ternate City is now very active in the campaign for Ternate tourism revival. All forms of historical heritage in Ternate become the object and the subject of reliable tourism, coupled with the uniqueness of Ternate community culture. On one occasion, the character of Ternate said as follows:

Ternate is not big, especially when compared with the island of Java. But the surrounds of Ternate will not be bored because it is not jammed. In Ternate the land is fertile and many customs are very distinctive and very potential to be used as tour packages. Not to mention when viewed the relic of the past. This shows that Ternate has advanced from time to time. Ternate central spice. Well, this spice herb that then enriches the history of the people of Ternate.

The informant's opinion above implies the desire to build Ternate from the tourism side considering the number of tourism potential owned by Ternate City. Funding issues, the quality of human resources, and the support of tourism facilities and infrastructure must be developed in Ternate. Heritage Historical or historical sites in Ternate to be a separate capital in an effort to provide employment-based tourism. Some examples of countries whose tourism sector is advancing because of the potential of the preserved past, developed and proclaimed among others the United States with its pride of democracy, Spain, France, Germany Russia with the legacy of royal dynasties in the past, Vietnam with the events of Vientamnya War, China with Chinese walls and so on and Singapore is very famous for the icon of the lion's statue of water.

Such conditions should also occur in Indonesia with a very beautiful natural diversity, a very distinctive cultural diversity, as well as the remnants of a remarkable past, as well as the city of Ternate. The city of Ternate has a stunning natural relief ranging from mountains to the sea and beaches, the existence of past relics such as Colonial Portuguese, Spanish and Dutch heritage fortresses, Ternate's cultural treasures as well as the rich culinary riches of Ternate. This is a reality, basic capital, wealth and character typical of Ternate City that is not necessarily owned by other regions. How to make the entire tourism potential of Ternate including a historical site as a cultural heritage has value and benefit for the sustainability of the population in Ternate. This means the existence of many historical sites to be the entrance to the opening of new jobs through the tourism sector. Types of job/new job opportunities that can be done related to the tourism sector such as providing tourist services that attract tourists. For example hospitality, travel agencies, restaurants, diving, surfing, local food product development for by the typical Ternate handbags and much more. This condition will be able to run well if supported by the implementation of holistic education in responding to the challenges possessed by the City of Ternate.

As an Indonesian tourist destination in Eastern Indonesia, based on field observations that have been done

so far can be mentioned several objects that can be visited as follows below.

Tabel 1

Destinasi Wisata Kota Ternate

\begin{tabular}{|c|c|c|c|}
\hline No & $\begin{array}{c}\text { Tourists Attractions } \\
\text { by Type }\end{array}$ & $\begin{array}{c}\text { Tourist Destination } \\
\text { Location }\end{array}$ & Attractiveness \\
\hline \multirow[t]{6}{*}{1} & Natural tourism & Mount Gamalama & $\begin{array}{l}\text { Active volcanoes with } \\
\text { dense forests. Full of } \\
\text { nutmeg and clove plants } \\
\text { that are very famous in } \\
\text { the colonial period }\end{array}$ \\
\hline & & $\begin{array}{l}\text { Small Tolire Lake dan } \\
\text { Big Tolire Lake }\end{array}$ & $\begin{array}{l}\text { Lake at the foot of Mount } \\
\text { Gamalama, the water is } \\
\text { green. And uniquely if } \\
\text { we throw a stone kea rah } \\
\text { stone did not get to the } \\
\text { lake }\end{array}$ \\
\hline & & Salamadaha Beach & $\begin{array}{l}\text { Beach with a very } \\
\text { beautiful mountain } \\
\text { backdrop, calm waves, } \\
\text { black sand, perfect for } \\
\text { diving and snorkeling }\end{array}$ \\
\hline & & Laguna Lake & $\begin{array}{l}\text { Very appropriate for } \\
\text { those who have a hobby } \\
\text { of fishing }\end{array}$ \\
\hline & & Harbour Beaches & $\begin{array}{l}\text { Ternate harbor which } \\
\text { connects between } \\
\text { islands, is very busy with } \\
\text { motor boats and around } \\
\text { the harbor with its } \\
\text { attractive traditional market }\end{array}$ \\
\hline & & Maitara Beach & $\begin{array}{l}\text { Which is known for the } \\
\text { beach a thousand bucks. } \\
\text { Because on the beach } \\
\text { there is a mountain } \\
\text { maitara used in pictures } \\
\text { of money Rp. } 1000\end{array}$ \\
\hline \multirow[t]{7}{*}{2} & Historical Tours & $\begin{array}{ll}\text { Kedaton } & \text { Ternate } \\
\text { Museum } & \end{array}$ & $\begin{array}{l}\text { Ternate Sultanate Center } \\
\text { with } \\
\text { architecture }\end{array}$ \\
\hline & & Kedaton Great Moscue & $\begin{array}{l}\text { The entry marker of } \\
\text { Islam in Ternate }\end{array}$ \\
\hline & & Kalamata Fort & $\begin{array}{l}\text { Colonial building for } \\
\text { defense }\end{array}$ \\
\hline & & Toluko Fort & $\begin{array}{l}\text { Colonial building for } \\
\text { defense }\end{array}$ \\
\hline & & Kastela Fort & $\begin{array}{l}\text { Colonialbuilding for } \\
\text { defense }\end{array}$ \\
\hline & & Oranje Fort & $\begin{array}{l}\text { Colonialbuilding for } \\
\text { defense }\end{array}$ \\
\hline & & Kota Naka Fort & $\begin{array}{l}\text { Colonial building for } \\
\text { defense }\end{array}$ \\
\hline \multirow[t]{6}{*}{3} & Culture tour & Adat joko kaha & $\begin{array}{l}\text { Traditional ceremony } \\
\text { welcomes guests }\end{array}$ \\
\hline & & cakalele/hasa Dance & Dance of War \\
\hline & & Dodengo Dance & Dance game hit blow \\
\hline & & Ronggeng Dance & $\begin{array}{l}\text { Public dance for the } \\
\text { public, performed by } \\
\text { male and female dancers }\end{array}$ \\
\hline & & $\begin{array}{ll}\text { Legu-Legu } & \text { dan } \\
\text { Dadangsa Dance } & \end{array}$ & $\begin{array}{l}\text { Great Dance at a great } \\
\text { ceremony }\end{array}$ \\
\hline & & Dabus/Badabus Dance & $\begin{array}{l}\text { Dancing by stab yourself } \\
\text { with sharp objects }\end{array}$ \\
\hline
\end{tabular}




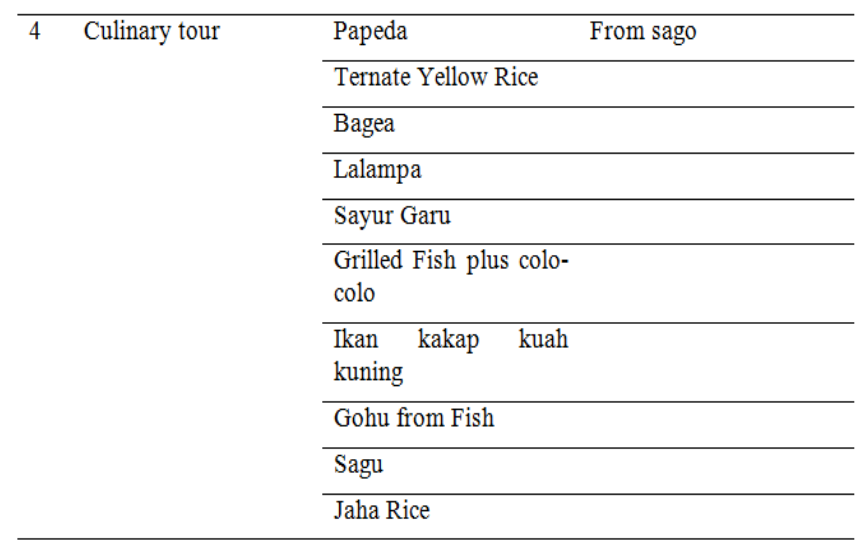

\section{Ternate Culture / Heritage Sites as an Object-Based} Education for Sustainable Development (ESD)

Education for Sustainable Development (hereinafter referred to as ESD) or education for sustainable development is the idea of education policy in order to foster and strengthen the mindset about the importance of education for the existence of a nation (WQA, 2010). As it has been revealed that ESD was raised since 1997 in conjunction with the Greek Declaration of Thessaloniki, as part of an evolutionary form of environmental education since 1972 (Bintari, 2014). UNESCO calls this paradigm with the terms Education for Sustainable Development (ESD) or if it becomes an Education for Sustainable Development (PUPB: in I made Gunamantha, 2010). In this research still used the term ESD, to be more consistent and familiar. In the observations made so far, the term ESD in education has not been widely known by teachers and principals, especially at the primary school level. Most of them still practice inadequate conventional teaching-learning activities to develop learning content with long-term issues.

ESD becomes an important issue in relation to the occurrence of changes in the natural environment due to the unlimited demand and unlimited needs of human life. The needs of both human physical and spiritual are often not enough with what is in the natural surroundings. The emergence of the human desire to have more of what is needed often raises unstoppable social upheaval and becomes a distinct imprint on the history of human civilization. Colonial Portuguese, Spanish, Dutch and other traces of human activity that always wants to master. Signs of colonization of the Nation is very clear in the region of Ternate.

Human behavior that tends to think narrowly and for the sake of a moment often takes unlimited natural resources and destroys the environment (Bintari, 2014). As a result of nature is getting exhausted and our children and grandchildren live to accept the consequences, such as floods, droughts, landslides and so forth. This is very visible in the situation of historical heritage in Ternate is less well maintained and continues to press the economic interests of the population in the region. Some of the physical buildings are not clean and densely populated with residents and street vendors. Ternate city government intervention for tourism development is very helpful for rescue this site.

The construction and guarding of historical sites as cultural heritage objects became part of the spirit of ESD as proposed by Cortese (1999), in I Made Gunamantha, 2010 is an effort of searching and awareness-raising to appreciate past works as a basis for self-identity. Historical / Cultural Heritage Sites are the real facts of a nation's travel process that must be known and understood the important meaning behind the facts found today.Their Kedaton's Heritage as Ternate City Museum is very important to know the traces of Ternate City hundreds of years ago. -the fortress built by the colonial government, although it leaves the bitterness of history but with it also can raise the spirit of heroic because our nation can finally drive them the invaders bravely.Because if we look at the existing colonial relics, crossed in our memories of the colonial power to suppress and take advantage for the glory of their country in Europe. Of course, this mindset exists only in resources that have historical consciousness and the future of the nation and that consciousness is gained through a good educational process. That is, it takes educated human resources who are able to see problems in various perspectives and holistic. Meanwhile, the educational and learning strategies were undertaken in Indonesia today is still limited to the provision of knowledge which still requires the hard work of all parties in characteristic learning.

More deeply, in one of his writings, Yulipriatno et al. (2013) emphasize the task of education that must be able to foster an understanding of the importance of sustainability and ecosystem balance, namely the understanding that humans are part of the ecosystem. Education should provide an understanding of the values of social and natural responsibility to provide students with the idea that they are part of a social system that must synergize with other humans and part of the natural system that must synergize with nature and its contents. With these values, there will be a critical understanding of the environment (social and natural) and all forms of intervention to the environment, good and bad, including development (Kemdiknas, 2010b).

Education greatly influences the physical development, the power of the soul (reason, taste, and will), social and human morality and is the most important tool for maintaining oneself and maintaining positive values (Setiawan, 2010). Of course with the impact, this education brings impact on the increase of knowledge and skills and will help in the formation of positive attitudes and behaviors. Eco-friendly behavior can be established as expected. Where the formation of behavior in accordance with the expected is determined by three things, namely: the formation of behavior with habits, the formation of behavior with the understanding and the formation of behavior with the model or example (Walgito, 2010).

Associated with the position of Ternate as a heritage city, a city rich in natural resources and rich with historical heritage sites that belong to the area of Culinary Heritage, is an important basic capital that can be used and developed in forming citizens of Ternate with a system of 
continuing education based on wealth nature and relics of historical objects as one model of character formation, environmental balance, mutual respect and have a sense of pride with the identity it has. Accordingly, through the values that exist in ESD can be one model of efforts to change behavior and lifestyle more positive and can appreciate the work of history as one of the evidence of the past with positive values in it. This condition is reflected from the existence of the people of Ternate City who still need a new understanding of how to appreciate the cultural heritage objects as part of the economic development and identity of the typical city of Ternate is very worthy of pride. The situation in the observation of historical objects in Ternate, especially in the colonial heritage fortresses, has long been untampered and in the last five years, the local government began to pay attention. One example of Fort Toluko which is good because there is a development cooperation with universities in Yogyakarta. This condition is not yet fully for the Oranje Fort. Fortress oranje is very sturdy with the structure of the typical colonial buildings, currently a residence of residents of a certain unity. Inside the fort, there is a housing that gives the impression of less tidy, and less comfortable for tourism. Currently, revitalization efforts continue to be done, starting with the land acquisition is a large enough cost. If this condition is left unchecked, it is not likely to remove traces of the past of Ternate society itself.

The values that can be developed in sustainable development in Ternate City are related to the existence of historical sites as cultural heritage objects with dimensions developed by Puslitjak Kemendikbud (2010) as follows: Table 2

Appreciate Ternate History Site as an Object of Sustainable Tourism Development

\begin{tabular}{|c|c|c|c|}
\hline No & Dimensions & $\begin{array}{c}\text { Historical Sites / Cultural } \\
\text { Heritage Sites }\end{array}$ & $\begin{array}{l}\text { Sustainable Tourism } \\
\text { Development }\end{array}$ \\
\hline 1 & $\begin{array}{l}\text { Respect the value and } \\
\text { rights of all human beings } \\
\text { and commitment to } \\
\text { economic justice for all. }\end{array}$ & $\begin{array}{l}\text { Natural Tourism } \\
\text { Historical Tours } \\
\text { Cultural / Artistic Tours } \\
\text { Culinary Tour }\end{array}$ & $\begin{array}{l}\text { Respect the value and } \\
\text { rights of all human } \\
\text { beings and commitment } \\
\text { to economic justice for } \\
\text { all. }\end{array}$ \\
\hline 2 & $\begin{array}{l}\text { Respect future } \\
\text { generations of human } \\
\text { rights and commitment to } \\
\text { intergenerational } \\
\text { responsibility. }\end{array}$ & $\begin{array}{l}\text { Natural Tourism } \\
\text { Historical Tours } \\
\text { Cultural / Artistic Tours } \\
\text { Culinary Tour }\end{array}$ & $\begin{array}{l}\text { Maintaining nature for } \\
\text { the needs of future } \\
\text { generations, } \\
\text { maintaining historical } \\
\text { sites for future } \\
\text { generations of learning, } \\
\text { fostering a culture of } \\
\text { tolerance. }\end{array}$ \\
\hline 3 & $\begin{array}{l}\text { Respect and care for } \\
\text { community life with its } \\
\text { diversity includes } \\
\text { protection and } \\
\text { improvement to the } \\
\text { ecosystem of the planet. }\end{array}$ & $\begin{array}{l}\text { Natural Tourism } \\
\text { Historical Tours } \\
\text { Cultural / Artistic Tours } \\
\text { Culinary Tour }\end{array}$ & $\begin{array}{l}\text { Raises efforts to } \\
\text { maintain, care and } \\
\text { protect, including } \\
\text { repairing from damage. }\end{array}$ \\
\hline 4 & $\begin{array}{l}\text { Appreciate cultural } \\
\text { diversity and } \\
\text { commitment to building } \\
\text { local and global cultural } \\
\text { tolerance, peace and non- } \\
\text { violence. }\end{array}$ & $\begin{array}{l}\text { Natural Tourism } \\
\text { Historical Tours } \\
\text { Cultural / Artistic Tours } \\
\text { Culinary Tour }\end{array}$ & $\begin{array}{l}\text { Bring out anti-conflict } \\
\text { anti-violence spirit that } \\
\text { comes from lack of } \\
\text { understanding of } \\
\text { identity and past } \\
\text { respectively }\end{array}$ \\
\hline
\end{tabular}

Looking at the above table, it can be seen that sustainable development / ESD becomes an important part of the larger development framework, especially for tourism in Ternate. There are some examples in certain areas that are destroying historical sites because of current capitalist economic interests. However, these values must also be accompanied by the awareness of the public to be able to appreciate the existing site belonging to all non-private / individual property as seen today in Ternate on some historical sites.

\section{E. Sustainable Tourism Development Model Site-Based History of Ternate City}

Sustainable tourism is defined by UNWTO (in Myra Gunawan and Oliver Ortis, 2012) as tourism that takes full account of current and future economic, social and environmental impacts, addresses the needs of visitors, the tourism industry, the environment and the host community. A sustainable tourism approach is designed to encourage positive impacts of tourism development on the social and cultural values of local communities and to recognize and manage any negative impacts. It is highly possible that the development of tourism with the number of visitors/tourists in and abroad will have an undesirable negative impact.

Sustainable tourism development should be able to offer a better environment for the community and create mutually beneficial relationships by placing local culture as part or even the core of tourism products (Rina Kurniawati, without years and Myra Gunawan, 2012). By adding sustainability approach Rina Kurniawati (without years) stated in the development of tourism, community empowerment through education, communication, strengthening tolerance and respect, cultural exchange, cooperation and peace can be achieved. At the same time, there may also be greater pride in local culture as well as the revitalization of tradition. There are nine principles of sustainable tourism development (Ratna Kurniawati, No year), namely: 1). participation, 2). participation of stakeholders, 3). local ownership, 4). sustainable use of resources, 5). accommodating the purposes of society, 6). attention to carrying capacity, 7). monitor and evaluation, 8). accountability, 9). training and promotion. These nine principles can be used as a model of tourism development in Ternate City by utilizing historical sites / cultural heritage that exists as follows below.

- Participation: in this context, Ternate people are fully involved in the development of tourism potential either directly or indirectly. Directly for example to maintain the security of Ternate City which is free from criminal acts, the people of Ternate are friendly and ready to answer the questions of tourists anywhere met. Indirectly for example maintaining the dignity of Ternate City as a proud heritage city.

- Stakeholder Involvement: in this context, all organizations/community groups, governments, tourism associations, business associations support all policies to build sustainable tourism.

- Local Ownership: in this context, tourism development in Ternate City should offer employment to local 
communities. Tourism supporting facilities such as hotels, restaurants, and others were first developed by the people of Ternate itself. If there is a lack of involvement by related parties to build networks and improve the quality of human resources. should be developed and maintained by local communities

- Sustainable use of resources, ie the use of local resources and avoiding excessive use of resources. Natural wealth in the city of Ternate well maintained, well used, along with the development of tourism Ternate City.

- Accommodate Community Objectives: Ternate Municipal People continue to be given insight into how to develop and serve holistic tourism services.

- Carrying Capacity: What is intended is the capacity of the land to be considered include the physical, natural, social and cultural carrying capacity of Ternate to be developed as much as possible which should always be monitored and evaluated.

- Monitor and Evaluation: In this context, Ternate local government prepares monitoring and evaluation instruments to become a tourism development benchmark developed.

- Accountability, ie Tourism Planning in Ternate City should pay great attention to job opportunities, revenues and public health improvements of Ternate City itself as reflected in development policies. The management and utilization of natural resources such as land, water, and air must ensure accountability and ensure that existing resources are not over-exploited.

- Training and Promotion: Sustainable tourism development requires the implementation of educational and training program programs to equip people's knowledge and improve business, vocational and professional skills. Training should cover topics on sustainable tourism, hospitality management, and other relevant topics.

Based on these principles can reinforce that the occurrence of systematic and sustainable cooperation hence the desire of Ternate City as the City of Pusaka become the center of eastern Indonesia tourism destinations. The sociopolitical conflicts that occurred in the Maluku region a few years ago should be an important part of repeating itself. However, various forms of the fact of conflict can serve as new historical facts as a place to learn.

History as events and historical objects as facts of events is an important marker in the course of a nation's history. Therefore, there is an adage from the First President of the Republic of Indonesia Soekarno who says JAS MERAH, never forget history. This is where the importance of studying history. However, it must be recognized by the onslaught of the value of globalization, characterized by the strong value of money and importance as the basis of relations, often can eliminate historical facts for economic interests. Through historical tours, natural attractions, sustainable cultural tourism is expected to grow the spirit of love and proud of their homeland, awakened the spirit of tolerance and then become social capital for the development of the nation and state of Indonesia into a big and advanced nation.

\section{CONCLUSIONS}

Traces of colonial heritage in Ternate can be seen from various objects of history / historical site history that currently become a Protected Object of Culture. The remains of these heritages become a very important source for generations to come. Therefore, the historical sites of Ternate identified in this study are important tourist objects that should be developed in a sustainable manner. There are seven historical sites / cultural heritage objects identified in this research: Museum Kedaton Ternate, Ternate Agung Mosque, Fortress Kastela, Fort Toluko, Kalamata fortress, Bull Oranje, and Citadel of Nala. Seven sites are conditions vary and still require government intervention to be used as an object of tourism which can then become an economic power for the people of Ternate. With the approach of education for sustainable development, the development of historical sites takes into account the needs and involves the community directly with the full results for the benefit of the people of Ternate and the wider Indonesian community.

\section{REFERENCES}

Adnan Amal dan Syamsir Andili (2003). Ternate dalam Perspektif Sejarah, dalam: Ternate, Kelahiran dan Sejarah Sebuah Kota Ternate: Pemerintah Kota Ternate.

(2009). Tahun -tahun Yang Menentukan Babullah Datu Syah Manamatkan Kehadiran Portugis di Maluku. PUKAT : IAIAN Alaudin Makasar.

Andi Atjo Rusli. (2008). Orang Ternate dan Kebudayaannya. Jakarta : Cikoro.

Askar Jaya. (2004). "Konsep Pembangunan Berkelanjutan". Materi Kuliah Pembangunan. Institut Pertanian Bogor.

Darmawijaya, dkk. (2014). Pasir, batu dan Etos Budaya : Catatan dari Maluku Utara. Yogyakarta: Leutikaprio.

Fakhriati. (2010). Sejarah Sosial Kesultanan Ternate. Jakarta: Puslitbang Lektur Keagamaan.

Gottschalk, Louis. (1985). "Understanding History: A Primer of Historical Methods". Alih Bahasa: Nugroho notosusanto. Mengerti Sejarah. Jakarta: UI Press.

I Made Gunamantha. (2010). “ Pendidikan Untuk Pembangunan Berkelanjutan . Mengapa, Apa dan Bagaimana”. Jurnal Pendidikan dan Pengajaran Jilid 43 Nomor 3 Oktober. Universitas Pendidikan Ganesha.

Irfana. (2014). "Bangsa Portugis Menjajah Indonesia". http://sejarah-indonesia.bl.ee/20/bangsa-portugismenjajah-indonesia.html, 3 mei 2014

Jefrison dan Rimadewi. (2012). "Arahan Revitalisasi Kawasan Cagar Budaya Kota Lama Siak". Jurnal Teknik POMITS Vol 1 No 1

Joko Waluyo. (2014). "Ternate Bakal Jadi Kota Pariwisata". Poskota.com 
Jusuf Abdulrahman. (2013). Kapita Selekta Sejarah, bahasa dan Budaya Moloku Kie Raha. Yogyakarta: Kanisius.

Ki Supriyoko. (2003). "Sistem Pendidikan Nasional dan Peran Budaya dalam Pembangunan Bekelanjutan". Makalah Seminar nasional di Kementerian Hukum dan HAM.

Myra Gunawan dan Oliver Ortis. (2012). Rencana Strategis Pariwisata Berkelanjutan dan Green Jobs Untuk Indonesia. Kerjasama ILO dengan Kementrian Pariwisata Republik Indonesia.

Mudji Sutrisno dan Hendar Putranto. (2005). Teori-Teori Kebudayaan. Jogjakarta: Kanisius.

Oteng, Haridjaja. (2014). “ Pengembangan tema KKn PPM Berbasis Education For Sustainable Development". Makalah workshop Penyusunan Proposal Hibah KKN PPM DP2M Dikti Kemendikbud, Hotel Salak Bogor, 5-7 April 2014.

Parakitri T Simbolon. (2006). Menjadi Indonesia. Jakarta : Kompas

Philip Suprastowo, (2012). Model Pendidikan Untuk Pembangunan Berkelanjutan Melalui kegiatan Intrakurikuler. Kemendikbud : Puslitjak

Rina Kurniawati. (tanpa tahun). Modul Pariwisata Berkelanjutan.

S.K. Kochhar. (2008). "teaching of History". Alih Bahasa : H Purwanta, Yovita Hardiwati. Pembelajaran Sejarah. Jakarta : Gramedia.

Sjamsuddin, Helius. (2007). Metodologi Sejarah. Yogyakarta : Ombak.

Shandy Marcelino Alfon. (tanpa Tahun). "Buku Fotografi Tentang Peninggalan Benteng Benteng di Ternate Maluku Utara.". Karya Ilmiah Program Studi Desain Komunikasi Visual Fakultas Seni dan Desain Universitas Kristen Petra Surabaya.

Sri Ngabekti. (2012). "Pendidikan Untuk Pembangunan Berkelanjutan : Kasus Pondok Pesantren Modern Selamat Kendal". Disertasi Prodi Ilmu Lingkungan Universitas Gadjah Mada.

Sulasman dan Setia Gumilar. (2013). Teori -Teori Kebudayaan: dari Teori Hingga Aplikasi. Bandung: Pustaka Setia.

Suparlan, Parsudi. (2004). Masyarakat dan Kebudayaan Perkotaan Perspektif Antropologi Perkotaan . YPKIK: Yayasan pengembangan Kajian Ilmu Kepolisian.

Undang Undang Nomor 10 tahun 2009 Tentang Kepariwisataan .

UNESCO. (Tanpa tahun). Berinvestasi dalam Keragaman.

Yuli Prianto. (2013). "Pendidikan Berperspektif Lingkungan Menuju Pembangunan Berkelanjutan Environmental Perspective Education Towards Sustainable Development." Jurnal Wacana. Vol 16 Nomor 1 Universitas Brawijaya.

Nia Sutisna. "Tesis. Upi.edu/directory/FIP/Jurusan Pendidikan Luar Biasa diunduh tanggal 25 Juni 2015. www.beritasatu .com. (2014). “. Legislator Ternate Minta Situs Sejarah Tetap Dilestarikan"

e-journal.uajy.ac.id/402/3/2MTSO104

Sabtu,

$$
15 \quad \text { Agustus }
$$

http://bentengmalut.blogspot.com/benda cagar budaya sebagai aset daerah

Kota Ternatehttp://id.wikipedia.org/wiki/Kota_Ternate http://www.bintari.org/index.php/in/publikasi/opini/101pendidikan-untuk-pembangunan-berkelanjutan, 5 mei 2014.

http://sibirumudaku.blogspot.com/2011/05/jejakternate.html

http://id.wikipedia.org/wiki/Sejarah_Indonesia\#Kolonisasi_P ortugis_dan_Spanyol

http://darikitauntukindonesia.blogspot.com/2013/06/peningg alan-arkeologi-kesultanan-ternate.html, 3 mei 2014 http://id.voi.co.id/voi-warna-warni/6063-jejak-portugis-diternate, 3 Mei 2014 